\title{
Investigating Phenotypic Variability in Colletotrichum lindemuthianum Populations
}

\author{
J. M. A. Pinto, R. Pereira, S. F. Mota, F. H. Ishikawa, and E. A. Souza
}

First, second, third, and fifth authors: Department of Biology, Universidade Federal de Lavras, Lavras 3037, 37200-000, Brazil; and fourth author: Colegiado de Engenharia Agronômica, Fundação Universidade Federal do Vale do São Francisco, Petrolina-PE. Accepted for publication 9 January 2012.

\section{ABSTRACT}

Pinto, J. M. A., Pereira, R., Mota, S. F., Ishikawa, F. H., and Souza, E. A. 2012. Investigating phenotypic variability in Colletotrichum lindemuthianum populations. Phytopathology 102:490-497.

Colletotrichum lindemuthianum, causal agent of anthracnose in the common bean, has wide genetic variability. Differential bean cultivars and morphological and physiological characteristics were used to analyze 74 isolates of $C$. lindemuthianum collected in two counties in the state of Minas Gerais, Brazil. Six different races were found, with a predominance of race 65 at both locations. Isolates were classified according to their sensitivities to the fungicide thiophanate-methyl, normally used in the control of common bean anthracnose. In all, $\approx 10 \%$ of isolates were resistant to the fungicide in vitro. Characteristics such as indexes of mycelia growth rate, colony diameter, sporulation capacity, and percentage of germination demonstrated the high genetic variability of $C$. lindemuthianum. We also observed variation in conidial cytology. The conidia of most isolates showed septa formation after germination, in contrast to septa absence, previously reported in the literature. Sexual and asexual reproduction were evaluated for mechanisms that may contribute in the generation of variability in $C$. lindemuthianum. Conidial anastomosis tubes were commonly found, indicating that asexual reproduction can help increase variability in this species. Information from this study confirmed high variability in $C$. lindemuthianum and will guide future studies in basic knowledge and applied technologies.
Anthracnose, caused by Colletotrichum lindemuthianum (Sacc. \& Magnus) Briosi \& Cavara, is one of the most important diseases that affects the common bean, especially during mild temperatures and moist weather conditions (17). Losses of $\leq 100 \%$ in common bean yield can be observed when infected seed are used and climatic conditions favor the pathogen (33). C. lindemuthianum is a filamentous fungus that reproduces asexually and presents septate and ramified mycelia (36). The pathogen's sexual phase is described as Glomerella lindemuthiana (32) and has been identified in field isolates from Brazil $(6,35)$. In addition to sexual recombination, other mechanisms that allow genetic material transfer have been described in the literature for this pathogen, such as a parasexual cycle (7) and asexual recombination via fusion of conidial anastomosis tubes (CATs) $(13,28)$.

Breeding for disease resistance, which reduces production cost and environmental contamination, is the most efficient strategy for the control of anthracnose (26). However, the major limitation for the development of durable resistance in common bean cultivars is the high pathogenic and genetic variability of $C$. lindemuthianum (22). Because of this high variability, constant monitoring of the fungus in the field is essential to support breeders in the development of resistant cultivars. Synthetic fungicides are also widely used in common bean crops to control anthracnose disease (41). Despite their efficacy, the constant use of these products results in the emergence of problems, such as the appearance of resistant pathogens and the contamination of both food and the environment (38).

The variability of $C$. lindemuthianum is also demonstrated in morphological, physiological, and cultural characteristics (34).

\section{Corresponding author: E. A. Souza; E-mail address: easouza@dbi.ufla.br}

* The $e$-Xtra logo stands for "electronic extra" and indicates that the online version contains one supplementary table.

http://dx.doi.org/10.1094/PHYTO-06-11-0179

(C) 2012 The American Phytopathological Society
Several characteristics of this pathogen that are essential for its development and dissemination, including mycelia growth rates, colony diameter, sporulation capacity, and germination percentage, show great variation between isolates, even within the same race (34). Another important phenotype used in the taxonomy of the genus Colletotrichum is conidial cytology, which measures the dimensions of nongerminated conidia and analyzes the presence of septa in germinated conidia (18). Evaluation of these characteristics in phytopathogens is also important as a morphological marker in genetic studies (34).

A population of 74 isolates of $C$. lindemuthianum, collected in two counties in the state of Minas Gerais, Brazil, was evaluated to identify the pathogenic, morphologic, and physiologic variability of this pathogen and its implications in the characterization of species, understanding of population dynamics, and common bean management. Characteristics of cell biology and fungal development and the possible mechanisms that could help increase variability in this species were analyzed. Isolates were also evaluated for their in vitro sensitivities to the fungicide thiophanate-methyl to assess the effectiveness of the active ingredient in the control of common bean anthracnose. Information presented in this study can be used to broaden the understanding of C. lindemuthianum biology and to facilitate common bean management.

\section{MATERIALS AND METHODS}

Fungal isolates. Isolates of $C$. lindemuthianum were obtained from bean pods, leaves, and stems of naturally infected common bean cultivars. Samples, one per plant, were collected during 2009 in two counties (Lavras and Lambari), where high anthracnose incidence in the state of Minas Gerais, Brazil was reported previously $(1,33)$. Small pieces of infected plant tissue were surface sterilized and placed on petri dishes containing M3 culture medium ( $10 \mathrm{~g}$ of sucrose, $20 \mathrm{~g}$ of agar, $2 \mathrm{~g}$ of $\mathrm{KH}_{2} \mathrm{PO}_{4}, 1 \mathrm{~g}$ of $\mathrm{MgSO}_{4} \cdot 7 \mathrm{H}_{2} \mathrm{O}, 6 \mathrm{~g}$ of peptone, and $1 \mathrm{~g}$ of yeast extract). In all, 
74 single conidia cultures were obtained and maintained in M3 medium in the dark (Supplementary Table).

Polymerase chain reaction analysis. Polymerase chain reaction (PCR) amplification was performed to confirm $C$. lindemuthianum isolates. The MAT1-2-1 HMG domain was amplified with the specific primers HMGCLF (5'-CATGCCGCAGT AAAGCAAAT-3') and HMGCLR (5'-ATCATCAGACGTTCTT TGTG-3') for $C$. lindemuthianum (10). DNA was extracted according to the methodology developed by Raeder and Broda (24). Amplification was performed using Taq DNA Polymerase kit (Invitrogen Life Technologies, Carlsbad, CA) in a total volume of $50 \mu \mathrm{l}$ containing $5 \mu \mathrm{l}$ of $10 \times$ PCR buffer, $1.5 \mu \mathrm{l}$ of $\mathrm{MgCl}_{2}$ $(50 \mathrm{mM}), 0.5 \mu \mathrm{l}$ of Taq DNA polymerase $(5 \mathrm{U} / \mu \mathrm{l}), 1 \mu \mathrm{l}$ of dNTPs $(10 \mathrm{mM}), 2.5 \mu \mathrm{l}$ of each primer $(100 \mathrm{mM})$, and $2 \mu \mathrm{l}$ of DNA $(10 \mathrm{ng} / \mu \mathrm{l})$. PCR reactions were carried out in an MJ96+/MJ96G thermocycler (Biocycler Technology Co., Hangzhou, Zhejiang) using an initial denaturation of 2 min at $94^{\circ} \mathrm{C}$; followed by 30 cycles of $60 \mathrm{~s}$ at $94^{\circ} \mathrm{C}, 30 \mathrm{~s}$ at $55^{\circ} \mathrm{C}$, and $30 \mathrm{~s}$ at $72^{\circ} \mathrm{C}$; and a final extension of $10 \mathrm{~min}$ at $72^{\circ} \mathrm{C}$. Amplified products were separated by electrophoresis on $1.0 \%$ (wt/vol) agarose gels using a 100-bp DNA ladder as molecular marker with $1 \times$ Tris-borate-EDTA buffer (0.45 M Tris-borate and 0.01 M EDTA, $\mathrm{pH} 8.0)$ for $3.5 \mathrm{~h}$ at $80 \mathrm{~V}$, stained with ethidium bromide, visualized under UV light (Fotodyne Ultraviolet Trans-illuminator; Fotodyne Inc., New Berlin, WI), and photographed using a Kodak EDA-290 camera (Kodak Company, Rochester, NY).

Pathogenicity assays. Eight seeds from each of 12 common bean differential cultivars proposed by Pastor-Corrales (20) ('Michelitte', 'Michigan Dark Red Kidney', 'Perry Marrow', 'Cornell 49242', 'Widusa', 'Kaboon', 'México 222', 'PI 207262', 'TO', 'TU', 'AB 136', and 'G2333') were used for the pathogenicity test. Seed were provided by the plant breeding program of Universidade Federal de Lavras, Brazil. Each isolate was inoculated in bean pods in culture medium and incubated at $22^{\circ} \mathrm{C}$ for 10 to 15 days in the dark to obtain high sporulation. Ten-dayold bean seedlings with fully expanded primary leaves were sprayed with conidial suspension $\left(1.2 \times 10^{6}\right.$ conidia $\left./ \mathrm{ml}\right)$. Inoculated plants were incubated in a moist chamber at $22^{\circ} \mathrm{C}$ with a 12-h photoperiod and a relative humidity of $98 \%$ for $48 \mathrm{~h}$.

At 10 days postinoculation, symptoms of the disease were scored according to the descriptive scale recommended by Rava et al. (25). Plants with disease reaction scores of 1 to 3 were considered resistant, whereas plants that were scored 4 to 9 were considered susceptible. The identified races were assigned a value based on the binary nomenclature system proposed by Habgood (12). The differential cultivars were arranged in a fixed order and receive a fixed value defined by the equation $2^{n-1}$, where 2 was the number of reaction classes (resistant or susceptible) and $n$ is the order number of the cultivar. Incompatible reaction has a value of zero and nullifies the cultivar value when multiplied by it. The compatible reaction has a value 1 and gives the same cultivar value when multiplied by it. Therefore, the total sum of the values from the compatible reaction gives the number that designates the race.

Fungal isolate resistance to thiophanate-methyl. Agar blocks (6 $\mathrm{mm}$ in diameter) containing mycelia from each $C$. lindemuthianum isolate were cut from the edge of colonies and placed in the middle of plates containing M3 medium with thiophanatemethyl (Cercobin 700 WP; Iharabras S/A Indústrias Químicas, Sorocaba, SP, Brazil). Thiophanate-methyl $(0.7 \mathrm{mg} / \mathrm{ml})$ was added to M3 medium after autoclaving. This fungicide presents broad-action spectrum and is used on a large scale in this concentration, according to Abreu (1), to control common bean anthracnose in the field (4). The controls of this assay consisted of the growth of the same isolates in M3 medium without thiophanate-methyl.

Radial growth values were measured in two perpendicular directions after incubation at $22^{\circ} \mathrm{C}$ for 15 days, and the means of two replicates were calculated (23). Mean percentages of growth of each isolate on M3 medium + thiophanate-methyl were compared with control growth. Sensitive, intermediate, or resistant isolates were defined as exhibiting $<10,10$ to 60 , and $>60 \%$ growth, respectively, compared with the controls (31).

Indexes of mycelial growth rate and colony diameter. Experiments were carried out in a completely randomized design (CRD) with four replicates. Each plot consisted of one petri dish. Mycelial plugs (6 $\mathrm{mm}$ in diameter) from the second subculture were placed in the middle of M3 plates, which were incubated at $22^{\circ} \mathrm{C}$ in the dark. Indexes of mycelial growth rate (IMGRs) were evaluated by taking average colony measurements (in centimeters) in two perpendicular directions every $24 \mathrm{~h}$ over 15 days and were estimated according to the expression IMGR $=\Sigma(D c-$ $D p) / N$, where $D c$ is average of current colony diameter, $D p$ is average of previous colony diameter, and $N$ is number of days after inoculation (19). Colony diameter was assessed by measuring the perpendicular diameter average of each colony (in centimeters) after 15 days.

Sporulation capacity and percentage of germination. Sporulation capacity was analyzed using a CRD with three replicates. Each of the $74 C$. lindemuthianum isolates was inoculated on sterilized green common bean pods that were then incubated at $22^{\circ} \mathrm{C}$ for 15 days in the dark. Each plot consisted of one bean pod, to which $3 \mathrm{ml}$ of water was added to obtain conidial suspensions. Concentration was determined by analysis of $50 \mu \mathrm{l}$ of each conidial suspension according to Dias (9), using a metallized hemacytometer (Hausser Scientific Company, Horsham, PA).

For the percentage of germination assays, conidial suspensions $\left(1.2 \times 10^{6} \mathrm{conidia} / \mathrm{ml}\right)$ were used for each isolate. Assays were performed using split plots in time in a CRD with two replicates. Conidial suspensions $(500 \mu \mathrm{l}$ total) were sprayed out on petri dishes containing agar-water medium. After 24 and $48 \mathrm{~h}$ at $22^{\circ} \mathrm{C}$ in darkness, 50 conidia from each replicate were evaluated under an optical microscope Olympus CX41 (Olympus Deutschland $\mathrm{GmbH}$, Hamburg, Germany). Conidial germination was defined as when the germ tubes presented size larger or equal to the smallest conidial diameter.

Conidial cytology and formation of CATs. Conidial suspensions $\left(1.2 \times 10^{6}\right.$ conidia/ml $)$ from 18-day-old cultures were prepared as described above. Next, 200- $\mu$ l drops of each suspension were placed in an eight-well slide culture chamber (Nalge Nunc International, Rochester, NY), and the suspensions were then incubated at $22^{\circ} \mathrm{C}$ in darkness for $24 \mathrm{~h}$. Calcofluor White (0.12 M; Sigma-Aldrich, St. Louis) was added to each well, and the samples were examined after 3 to $4 \mathrm{~min}$ at room temperature using an inverted epifluorescence microscope (Zeiss Axio Observer Z1; Carl Zeiss Inc., Jena, Germany). Fluorescence was detected at $420 / 70 \mathrm{~nm}$ using a $\times 40$ objective lens. Images from the epifluorescence microscope were captured using Zeiss Axiovision software and were processed further in ImageJ 1.41 software (U.S. National Institutes of Health, Bethesda, MD).

For cytological measurements, 30 nongerminated conidia from each isolate were analyzed using CRD. The width and length of conidia (in micrometers) were measured using Image Tool 3.0 software (University of Texas Health Science Center, San Antonio). After $24 \mathrm{~h}$, germinated conidia from each isolate were classified with or without septa, and the percentage of septa formation was estimated. CAT fusion was quantified as the percentage of conidia or conidia germlings involved in fusion, using data from three replicates, with 200 conidia/replicate after $24 \mathrm{~h}$ of incubation (16).

Mycelial and sexual compatibility. Mycelial discs of $C$. lindemuthianum isolates were paired in all combinations on M3 medium plates using two replicates according to the CRD. After 15 days at $22^{\circ} \mathrm{C}$ in the dark, the pairings were evaluated. Sexual compatibility was indicated by the formation of a dark line of 
perithecia at the junction of the colonies. Mycelial compatibility was characterized by the mycelial mixture in the contact zone between two colonies.

Statistical analysis. Data were submitted to analysis of variance (ANOVA) and means were compared by the Scott-Knott test $(P=0.05)$ using the statistical program MSTAT-C 1.0 (Michigan State University, East Lansing).

\section{RESULTS}

PCR analysis. All isolates were collected from common bean cultivars, of which the etiologic agent of anthracnose is $C$. lindemuthianum. However, because of great interstrain morphological variability, these additional PCR assays were performed to confirm species. All evaluated isolates amplified a 200-bp fragment for the MAT1-2-1 HMG domain (10), confirming they were isolates of the $C$. lindemuthianum (Fig. 1E).

Pathogenicity assays. Isolates used in this study showed different virulence patterns when inoculated in the 12 differential cultivars (Table 1). Six races were identified from the 74 isolates. Races 65 and 81 were more prevalent, accounting for 58.11 and $18.92 \%$ of the isolates, respectively. In Lavras-MG, race 65 $(82.15 \%)$ was predominant, and only two other races were identified (races 1 and 81). However, in Lambari-MG, although race $65(42.2 \%)$ was more prevalent, five other races were found, accounting for the county's higher pathogenic variability.

Thiophanate-methyl resistance. Of the isolates used in this study, $68.9 \%$ were sensitive to thiophanate-methyl, $21.6 \%$ were classified as intermediate sensitivity, and only $9.5 \%$ showed resistance to thiophanate-methyl in vitro (Table 1). Plates used as controls in this experiment exhibited radial growth, which was compatible with the colony diameter assay results for these isolates (data not shown).

IMGRs and colony diameter. The 74 isolates were grouped in four different groups according to IMGRs and colony diameters (Table 2). Isolates with lower mycelial growth rates exhibited a lower radial growth, except for isolate LV 157, which was classified in a distinct group in both analyses. For both analyses, isolates showed great variability, and average growth (IMGR) varied from $1.76 \mathrm{~cm} /$ day (LV 187) to $4.5 \mathrm{~cm} /$ day (LV 186); colony diameter varied from $3.2 \mathrm{~cm}$ (LV 187) to $7.3 \mathrm{~cm}$ (LV 186) after 15 days.

Sporulation capacity and percentage of germination. Sporulation capacity data did not meet the assumptions of the ANOVA.
Transformation of data was required to fit the homogeneity of variances and normality of errors. A logarithmic transformation was used as suggested by Box and Cox (5). Mean tests classified the 74 isolates into five groups (Table 2). Sporulation data were variable, and the numbers of conidia varied from $0.13 \times 10^{6}$ conidia/ml (LV 155) to $18.87 \times 10^{6}$ conidia/ml (LV 122).

The statistical analyses performed for conidial germination rates showed that all factors were significantly different: strain $(P<0.0001)$, incubation time $(P<0.0001)$, and the strain-time interaction $(P<0.0001)$. Significant interactions indicated that percentages of germinating isolates were not coincident at both times of incubation assessed ( 24 and $48 \mathrm{~h}$ ). For example, isolate LV 121 was classified in the low germination percentage group at $24 \mathrm{~h}$; however, this isolate exhibited an intermediate germination percentage at $48 \mathrm{~h}$. Thus, mean tests were performed independently for each evaluation time. Different groups were formed according to germination percentages (Table 3). Isolate LV 190 exhibited higher germination percentages at $24 \mathrm{~h}(88.5 \pm 12.02 \%)$ and $48 \mathrm{~h}(94.5 \pm 4.76 \%)$, whereas some strains (LV 122, LV 137, LV 142, and LV187) still had $<30 \%$ germinated conidia at $48 \mathrm{~h}$ (Table 3).

Conidial cytology and formation of CATs. Significant statistical variations $(P<0.05)$ were observed for the width and length of conidia. Width varied from $4.09 \mu \mathrm{m}$ (LV 158) to $6.19 \mu \mathrm{m}$ (LV 159), forming three groups of statistically different isolates (Table 3). Measurement of conidia length yielded four different groups, with measurements varying from $14.46 \mu \mathrm{m}$ (LV 136) to $18.98 \mu \mathrm{m}$ (LV 143) (Table 3).

After $24 \mathrm{~h}$ of incubation in water, CAT fusion was not observed in four isolates (LV 157, LV 178, LV 184, and LV 201); thus, they were not included in the statistical analysis. From the 70 isolates analyzed, five groups were formed (Table 3). LV 121 exhibited the highest percentage of CAT fusion $(\approx 60 \%)$ (Fig. 1B and C), with long chains of conidia visualized (Fig. 1A). Evaluation of germlings indicated that only 11 isolates (LV 122, LV 143, LV 155, LV 171, LV 172, LV 182, LV 187, LV 195, LV 199, LV 200, and LV 203) did not show septa formation after germination (Fig. 1D). The percentage of conidia with septa after germination varied among the other 63 isolates evaluated, with values of conidia with septa ranging from 6\% (LV 170) to 88\% (LV 139) (Fig. 2).

Mycelial and sexual compatibility. Isolate pairing resulted in 48 combinations $(1.78 \%$ of the total) that had sexual compati-
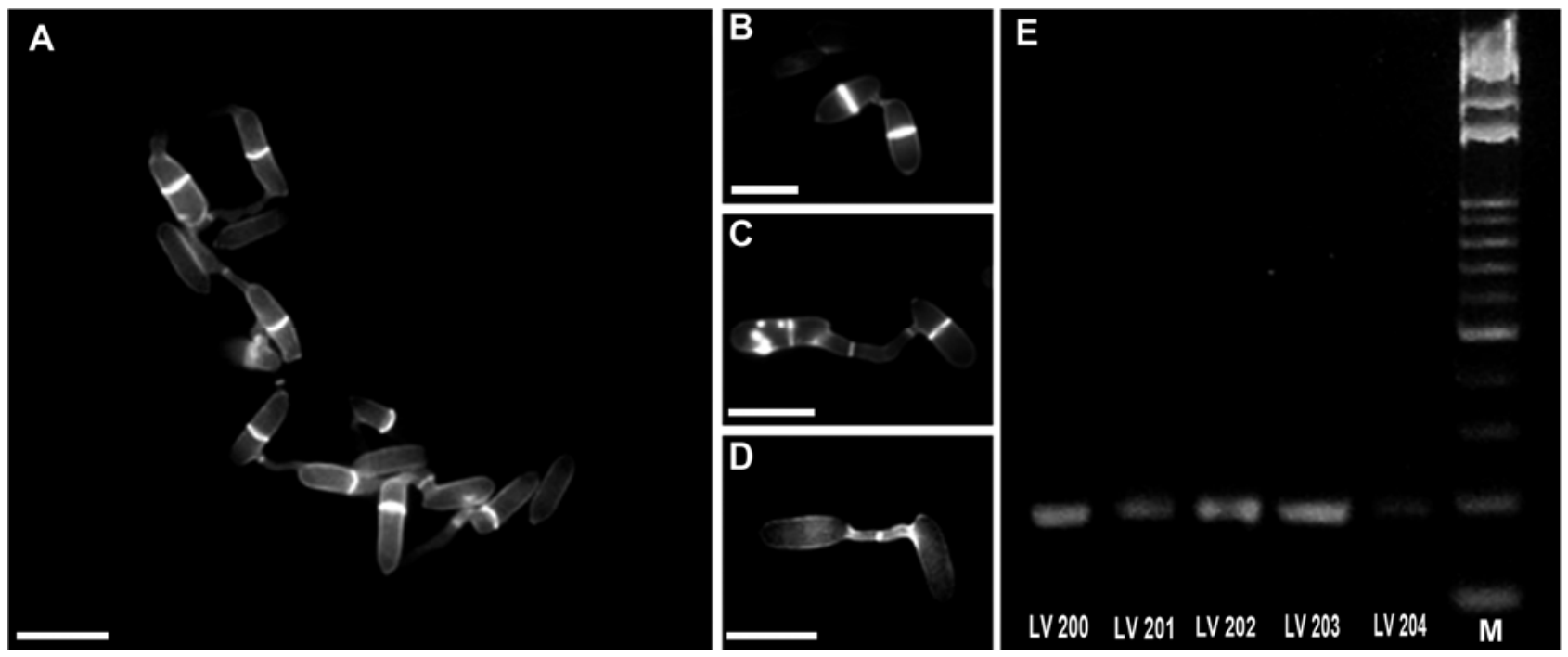

Fig. 1. Conidial anastomosis tube (CAT) fusion in different Colletotrichum lindemuthianum isolates stained with Calcofluor White (0.12 M) and polymerase chain reaction (PCR) amplification products from five representative isolates and (M) molecular marker (100-bp ladder). A, Chain of fused conidia from isolate LV 146; B, conidia fusion from isolate LV 135; C, conidia fusion from isolate LV 138; and D, conidia fusion from isolate LV 174. E, PCR amplification products obtained using primers HMGCLF and HMGCLR for indicated isolates. Bar: $10 \mu \mathrm{m}$. 
bility, marked by the presence of a dark contact line between pairings. However, none of the 48 combinations showed viable and fertile perithecia in the contact line after 15 days of incubation. Microscopic analysis revealed only the formation of protoperithecia, without production of asci and ascospores (data not shown). Isolates LV 195 and LV 141 were compatible in a higher number of combinations, 12.33 and $10.96 \%$, respectively (Table 1). A group of 30 isolates was incompatible in all combinations. Mycelial compatibility was not observed in any pairings.

\section{DISCUSSION}

All traits evaluated in this study demonstrated high variability in $C$. lindemuthianum populations. Pathogenicity tests revealed six virulence patterns in the 74 isolates of $C$. lindemuthianum studied (Table 1). These results show that $C$. lindemuthianum is a highly variable plant pathogen, especially considering that sampling was performed in only two counties, Lavras and Lambari, both in the state of Minas Gerais, Brazil, in 2009. Race 65 was most prevalent $(62.16 \%)$ in both counties and was identified in $82.14 \%$ of the isolates collected in Lavras. Although the high prevalence of race 65 in Brazil has been confirmed in previous studies $(15,37)$, the infected material was collected from a single host (BRS Majestoso cultivar) in Lavras (Supplementary Table 1). This fact may have contributed to the high prevalence of the race in our report.

Five other races of $C$. lindemuthianum were identified in this study: race $81(18.92 \%)$, race $73(9.46 \%)$, race $66(2.70 \%)$, race $64(8.11 \%)$, and race $1(2.70 \%)$ (Table 1$)$. Race 66 has not been previously reported in Minas Gerais $(33,37)$. Despite its low prevalence, this race must not be ignored, because an emergence of new virulence alleles may promote the breakdown of genetic resistance in the improved cultivars that are currently used. Therefore, monitoring races in producing areas of the common bean is important for plant breeding programs because this monitoring allows for the identification of newly emerging pathogenic races and new sources of resistance.

In addition to genetic resistance, the use of fungicide is a strategy often employed to control pathogens. Chemical control of anthracnose is achieved with the fungicide Cercobin 700, which has thiophanate-methyl as its active ingredient (1). The effect of this fungicide in reducing in vitro mycelial growth of $C$. lindemuthianum isolates was evaluated. The results showed that 9.5\% of the isolates studied were resistant (Table 1). In Brazil, cultivation of common bean occurs three seasons a year, meaning that inoculum is constantly present in the field. Therefore, the fungus is exposed to the fungicide continuously, thus providing opportunity for the selection of resistant individuals in the pathogen population. In addition, thiophanate-methyl is a systemic fungicide that has a specific mode of action at a site of the pathogen's metabolism, facilitating the emergence of resistant individuals in the population (4). The results suggest that studies are needed to determine the best strategies for the efficient use of fungicides in addition to genetic resistance.

Although all morphological and physiological characteristics evaluated in this study showed high variability in $C$. lindemuthianum, no grouping was observed in relation to collection local or pathogenic race. In analyzing race 65 variability, the most prevalent race in the study, we observed variation for all traits. Physiological traits showed significant differences $(P<0.05)$ in mean diameter and IMGR between $C$. lindemuthianum isolates. IMGR values for all isolates were $>1.70 \mathrm{~cm} /$ day, whereas isolates evaluated by Souza et al. (34) grew $<1.11 \mathrm{~cm} /$ day. The differences in IMGR values found by these authors may be related to genetic factors and also the number of subcultures and the storage times prior to evaluation of the isolates. In this study, we used fresh isolates, which were evaluated a few weeks after collection of the infected samples in the field.
TABLE 1. Race classification, percentage of colony growth inhibition by fungicide thiophanate methyl, and percentage of compatible sexual crosses for 74 Colletotrichum lindemuthianum isolates

\begin{tabular}{|c|c|c|c|}
\hline Isolate & Race & Inhibition $(\%)^{\mathrm{y}}$ & Compatible crosses $(\%)^{\mathrm{z}}$ \\
\hline LV 121 & 64 & $100.00 \mathrm{~S}$ & nc \\
\hline LV 122 & 64 & $7.63 \mathrm{R}$ & nc \\
\hline LV 130 & 81 & $4.29 \mathrm{R}$ & nc \\
\hline LV 131 & 65 & $100.00 \mathrm{~S}$ & $\mathrm{nc}$ \\
\hline LV 132 & 81 & $86.60 \mathrm{~S}$ & $\mathrm{nc}$ \\
\hline LV 134 & 65 & $100.00 \mathrm{~S}$ & 1.37 \\
\hline LV 135 & 81 & $75.44 \mathrm{~S}$ & 1.37 \\
\hline LV 136 & 65 & $52.78 \mathrm{I}$ & 1.37 \\
\hline LV 137 & 81 & $15.56 \mathrm{I}$ & 1.37 \\
\hline LV 138 & 64 & $88.19 \mathrm{~S}$ & 6.85 \\
\hline LV 139 & 65 & $64.43 \mathrm{~S}$ & 5.48 \\
\hline LV 140 & 65 & $25.00 \mathrm{I}$ & $\mathrm{nc}$ \\
\hline LV 141 & 66 & $78.13 \mathrm{~S}$ & 10.96 \\
\hline LV 142 & 81 & $9.65 \mathrm{R}$ & nc \\
\hline LV 143 & 64 & $100.00 \mathrm{~S}$ & $\mathrm{nc}$ \\
\hline LV 144 & 1 & $5.26 \mathrm{R}$ & 2.74 \\
\hline LV 145 & 65 & $82.15 \mathrm{~S}$ & 4.11 \\
\hline LV 146 & 64 & $11.97 \mathrm{I}$ & 2.74 \\
\hline LV 147 & 65 & $6.90 \mathrm{R}$ & 1.37 \\
\hline LV 148 & 65 & $12.28 \mathrm{I}$ & 1.37 \\
\hline LV 149 & 81 & 20.37 I & 1.37 \\
\hline LV 152 & 64 & $12.50 \mathrm{I}$ & 1.37 \\
\hline LV 153 & 81 & $26.47 \mathrm{I}$ & 1.37 \\
\hline LV 154 & 1 & $70.76 \mathrm{~S}$ & 1.37 \\
\hline LV 155 & 81 & $100.00 \mathrm{~S}$ & $\mathrm{nc}$ \\
\hline LV 156 & 73 & $23.00 \mathrm{I}$ & $\mathrm{nc}$ \\
\hline LV 157 & 73 & $10.78 \mathrm{I}$ & 1.37 \\
\hline LV 158 & 73 & $81.04 \mathrm{~S}$ & 1.37 \\
\hline LV 159 & 73 & $71.31 \mathrm{~S}$ & $\mathrm{nc}$ \\
\hline LV 160 & 65 & $84.69 \mathrm{~S}$ & $\mathrm{nc}$ \\
\hline LV 161 & 65 & $80.77 \mathrm{~S}$ & 5.48 \\
\hline LV 162 & 65 & $72.22 \mathrm{~S}$ & 2.74 \\
\hline LV 163 & 65 & $51.39 \mathrm{I}$ & $\mathrm{nc}$ \\
\hline LV 164 & 65 & $66.96 \mathrm{~S}$ & $\mathrm{nc}$ \\
\hline LV 165 & 81 & $13.79 \mathrm{I}$ & 2.74 \\
\hline LV 166 & 65 & $100.00 \mathrm{~S}$ & $\mathrm{nc}$ \\
\hline LV 167 & 65 & $76.67 \mathrm{~S}$ & $\mathrm{nc}$ \\
\hline LV 168 & 65 & $76.36 \mathrm{~S}$ & 1.37 \\
\hline LV 169 & 65 & $85.92 \mathrm{~S}$ & 2.74 \\
\hline LV 170 & 81 & $70.42 \mathrm{~S}$ & $\mathrm{nc}$ \\
\hline LV 171 & 66 & $100.00 \mathrm{~S}$ & 1.37 \\
\hline LV 172 & 65 & $81.14 \mathrm{~S}$ & $\mathrm{nc}$ \\
\hline LV 173 & 65 & $100.00 \mathrm{~S}$ & $\mathrm{nc}$ \\
\hline LV 174 & 65 & $91.83 \mathrm{~S}$ & $\mathrm{nc}$ \\
\hline LV 175 & 65 & $69.79 \mathrm{~S}$ & 5.48 \\
\hline LV 176 & 65 & $78.00 \mathrm{~S}$ & 1.37 \\
\hline LV 177 & 65 & $86.57 \mathrm{~S}$ & 1.37 \\
\hline LV 178 & 65 & $100.00 \mathrm{~S}$ & 1.37 \\
\hline LV 179 & 65 & $80.21 \mathrm{~S}$ & 1.37 \\
\hline LV 180 & 65 & $77.28 \mathrm{~S}$ & $\mathrm{nc}$ \\
\hline LV 181 & 65 & $76.32 \mathrm{~S}$ & nc \\
\hline LV 182 & 81 & $5.88 \mathrm{R}$ & 1.37 \\
\hline LV 183 & 73 & $100.00 \mathrm{~S}$ & 1.37 \\
\hline LV 184 & 65 & 56.86 I & 1.37 \\
\hline LV 185 & 65 & $91.93 \mathrm{~S}$ & 2.74 \\
\hline LV 186 & 65 & $21.24 \mathrm{I}$ & 2.74 \\
\hline LV 187 & 81 & $89.07 \mathrm{~S}$ & $\mathrm{nc}$ \\
\hline LV 188 & 65 & $60.16 \mathrm{~S}$ & $\mathrm{nc}$ \\
\hline LV 189 & 65 & $92.56 \mathrm{~S}$ & $\mathrm{nc}$ \\
\hline LV 190 & 65 & $89.58 \mathrm{~S}$ & $\mathrm{nc}$ \\
\hline LV 191 & 65 & $100.00 \mathrm{~S}$ & $\mathrm{nc}$ \\
\hline LV 192 & 65 & $85.46 \mathrm{~S}$ & 5.48 \\
\hline LV 193 & 65 & $61.36 \mathrm{~S}$ & 2.74 \\
\hline LV 194 & 65 & $100.00 \mathrm{~S}$ & 4.11 \\
\hline LV 195 & 65 & $100.00 \mathrm{~S}$ & 12.33 \\
\hline LV 196 & 81 & $91.00 \mathrm{~S}$ & 2.74 \\
\hline LV 197 & 65 & $100.00 \mathrm{~S}$ & $\mathrm{nc}$ \\
\hline LV 198 & 65 & $94.35 \mathrm{~S}$ & 6.85 \\
\hline LV 199 & 65 & $100.00 \mathrm{~S}$ & 6.85 \\
\hline LV 200 & 65 & $21.16 \mathrm{I}$ & $\mathrm{nc}$ \\
\hline LV 201 & 81 & $2.68 \mathrm{R}$ & 5.48 \\
\hline LV 202 & 73 & $76.92 \mathrm{~S}$ & nc \\
\hline LV 203 & 65 & $100.00 \mathrm{~S}$ & 1.37 \\
\hline LV 204 & 73 & $31.45 \mathrm{I}$ & 1.37 \\
\hline
\end{tabular}

y Inhibition by fungicide. Resistance to thiophanate-methyl: $\mathrm{S}=$ sensitive, $\mathrm{R}=$ resistant, and I = intermediate.

$\mathrm{z}$ Abbreviation: $\mathrm{nc}=$ compatible sexual crosses were not observed for this isolate. 
Physiological traits can also help directly classify isolates that have greater capacity for spread in the field and that can easily establish themselves on host surfaces. The rate of sporulation of a pathogen, for example, influences the determination of their capacity for dispersal, affecting the spatial distribution of the species (21). Furthermore, $C$. lindemuthianum has been reported to have limited dispersal capacity, which occurs preferentially between different parts of the plant and occasionally between adjacent plants (35). Therefore, studying the capacities for sporulation of different $C$. lindemuthianum isolates may assist in inferring which isolates have greater chances for spread in the field and high spore production, such as isolate LV 122. Initial establishment and development of plant pathogens in their hosts requires germination to hyphal form and, subsequently, production of infective structures (40). In this study, high levels of diversity were detected when we analyzed the germination of conidia from different strains, including between the two evaluated periods ( 24 and $48 \mathrm{~h}$ ). Knowledge of the process of spore germination is important for attaining a broader understanding of the events before and after host infection by a pathogen (14).

Moreover, the analysis of morphological traits is useful to verify species variability, in genetic analysis (e.g., when isolates identified differed in a given trait), and in the differentiation of Colletotrichum spp. $(18,34)$. Cytological analysis in this study measured the lengths and widths of ungerminated conidia and the presence of septa in germinated conidia. The ranges of variation in conidial length $(14.46$ to $18.98 \mu \mathrm{m})$ and width (4.09 to 6.19 $\mu \mathrm{m})$ are in agreement with those reported for the species $(27,29)$. However, the presence of septa in germinated conidia contradicts what has been reported in the literature (18). In that study, the authors state that $C$. lindemuthianum spores remain nonseptate after germination. On the basis of our results, this species' germinated conidia may be inferred to have varying percentages of septa formation; in our analyses, isolates exhibited percentages of conidia with septa of 6 to $89 \%$ (Fig. 2). This contradiction may be attributed to the fact that O'Connell et al. (18) evaluated only two C. lindemuthianum isolates, which did not cover the entire variability for this trait. Therefore, our data suggests that this trait, the absence of septa in germinated conidia, cannot be used for species classification, as has been previously proposed (18). C. lindemuthianum isolates may or may not produce septate conidia after germination when using a large population. PCR reactions using primers specific for the $C$. lindemuthianum MAT1-2-1 HMG domain (10) confirmed that all strains isolated were from this species.

Some of the mechanisms studied that could help the generation of the observed variability are sexual recombination $(6,35)$, the parasexual cycle (7), and asexual recombination via CAT fusion $(16,28)$. For sexual recombination, only $1.78 \%$ of the combinations evidenced sexual compatibility. However, these pairings did not produce asci or ascospores. Studies of the sexual cycle of the Colletotrichum genus indicate that genetic control of reproduction in this pathogen is not equivalent to a simple mating system; more than one locus in the genome is likely involved in the control $(2,39)$. The production of protoperithecia between

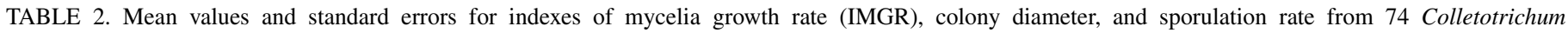
lindemuthianum isolates investigated

\begin{tabular}{|c|c|c|c|c|c|c|c|}
\hline Isolate & $\begin{array}{c}\text { IMGR } \\
(\mathrm{cm} / \text { day })^{\mathrm{z}}\end{array}$ & $\begin{array}{l}\text { Colony diameter } \\
\qquad(\mathrm{cm})^{\mathrm{z}}\end{array}$ & $\begin{array}{l}\text { Sporulation rate } \\
\left(\times 10^{6} \text { conidia } / \mathrm{ml}\right)^{\mathrm{z}}\end{array}$ & Isolate & $\begin{array}{c}\text { IMGR } \\
(\mathrm{cm} / \text { day })^{\mathrm{z}}\end{array}$ & $\begin{array}{l}\text { Colony diameter } \\
\qquad(\mathrm{cm})^{\mathrm{z}}\end{array}$ & $\begin{array}{l}\text { Sporulation rate } \\
\left(\times 10^{6} \text { conidia } / \mathrm{ml}\right)^{\mathrm{z}}\end{array}$ \\
\hline LV 121 & $2.00 \pm 0.62 \mathrm{a}$ & $3.50 \pm 9.42 \mathrm{a}$ & $16.33 \pm 8.07 \mathrm{c}$ & LV 168 & $3.35 \pm 0.46 \mathrm{c}$ & $5.53 \pm 6.95 \mathrm{c}$ & $12.52 \pm 4.01 \mathrm{c}$ \\
\hline LV 122 & $3.55 \pm 0.53 \mathrm{c}$ & $5.83 \pm 7.93 c$ & $18.87 \pm 9.74 \mathrm{c}$ & LV 169 & $4.40 \pm 0.25 \mathrm{~d}$ & $7.13 \pm 4.11 \mathrm{~d}$ & $5.23 \pm 3.75 b$ \\
\hline LV 130 & $4.33 \pm 0.24 \mathrm{~d}$ & $7.00 \pm 3.56 \mathrm{~d}$ & $10.43 \pm 3.30 b$ & LV 170 & $4.40 \pm 0.30 \mathrm{~d}$ & $7.10 \pm 4.55 \mathrm{~d}$ & $3.57 \pm 1.17 \mathrm{a}$ \\
\hline LV 131 & $4.03 \pm 0.61 \mathrm{~d}$ & $6.65 \pm 9.15 \mathrm{~d}$ & $1.28 \pm 0.98 \mathrm{a}$ & LV 171 & $3.78 \pm 0.23 \mathrm{c}$ & $6.20 \pm 3.83 c$ & $7.45 \pm 3.28 b$ \\
\hline LV 132 & $3.38 \pm 0.62 \mathrm{c}$ & $5.58 \pm 9.32 \mathrm{c}$ & $1.93 \pm 0.53 \mathrm{a}$ & LV 172 & $3.18 \pm 0.41 b$ & $5.28 \pm 6.13 b$ & $1.20 \pm 0.45 \mathrm{a}$ \\
\hline LV 134 & $3.27 \pm 0.27 b$ & $5.40 \pm 4.08 \mathrm{~b}$ & $1.48 \pm 0.41 \mathrm{a}$ & LV 173 & $4.30 \pm 0.30 \mathrm{~d}$ & $6.95 \pm 4.51 \mathrm{~d}$ & $1.10 \pm 1.09 \mathrm{a}$ \\
\hline LV 135 & $3.45 \pm 0.29 \mathrm{c}$ & $5.68 \pm 4.43 \mathrm{c}$ & $1.57 \pm 0.44 \mathrm{a}$ & LV 174 & $2.95 \pm 0.87 b$ & $4.93 \pm 13.1 \mathrm{~b}$ & $1.22 \pm 1.11 \mathrm{a}$ \\
\hline LV 136 & $4.43 \pm 0.43 \mathrm{~d}$ & $7.15 \pm 6.45 \mathrm{~d}$ & $3.07 \pm 1.91 \mathrm{a}$ & LV 175 & $2.87 \pm 0.53 b$ & $4.80 \pm 8.04 b$ & $1.77 \pm 0.26 \mathrm{a}$ \\
\hline LV 137 & $2.65 \pm 0.29 b$ & $4.48 \pm 4.27 b$ & $12.23 \pm 6.98 \mathrm{c}$ & LV 176 & $2.97 \pm 0.47 b$ & $4.95 \pm 7.05 b$ & $2.18 \pm 1.31 \mathrm{a}$ \\
\hline LV 138 & $4.63 \pm 0.35 \mathrm{~d}$ & $7.20 \pm 9.09 \mathrm{~d}$ & $0.98 \pm 0.20 \mathrm{a}$ & LV 177 & $4.12 \pm 0.55 \mathrm{~d}$ & $6.68 \pm 8.26 \mathrm{~d}$ & $2.52 \pm 0.83 \mathrm{a}$ \\
\hline LV 139 & $3.07 \pm 0.66 b$ & $5.15 \pm 9.29 b$ & $1.90 \pm 1.50 \mathrm{a}$ & LV 178 & $3.35 \pm 0.50 \mathrm{c}$ & $5.53 \pm 7.50 \mathrm{c}$ & $1.10 \pm 0.26 \mathrm{a}$ \\
\hline LV 140 & $2.75 \pm 0.27 b$ & $4.63 \pm 4.03 \mathrm{~b}$ & $13.25 \pm 3.49 c$ & LV 179 & $2.85 \pm 0.31 b$ & $4.78 \pm 4.57 b$ & $1.40 \pm 0.83 \mathrm{a}$ \\
\hline LV 141 & $3.90 \pm 0.23 \mathrm{~d}$ & $6.35 \pm 3.42 \mathrm{~d}$ & $7.72 \pm 5.09 \mathrm{~b}$ & LV 180 & $4.07 \pm 0.66 \mathrm{~d}$ & $6.60 \pm 9.83 d$ & $2.77 \pm 2.14 \mathrm{a}$ \\
\hline LV 142 & $3.43 \pm 0.65 \mathrm{c}$ & $5.65 \pm 9.75 c$ & $9.90 \pm 2.98 b$ & LV 181 & $2.17 \pm 0.29 \mathrm{a}$ & $3.75 \pm 4.36 \mathrm{a}$ & $2.70 \pm 1.28 \mathrm{a}$ \\
\hline LV 143 & $3.90 \pm 0.18 \mathrm{~d}$ & $6.35 \pm 2.65 \mathrm{~d}$ & $4.05 \pm 2.77 \mathrm{~b}$ & LV 182 & $4.17 \pm 0.24 \mathrm{~d}$ & $6.75 \pm 3.70 \mathrm{~d}$ & $8.18 \pm 1.95 b$ \\
\hline LV 144 & $2.22 \pm 0.24 \mathrm{a}$ & $3.83 \pm 3.59 \mathrm{a}$ & $13.07 \pm 3.10 \mathrm{c}$ & LV 183 & $2.38 \pm 0.38 \mathrm{a}$ & $4.08 \pm 5.68 \mathrm{a}$ & $3.90 \pm 1.34 \mathrm{a}$ \\
\hline LV 145 & $3.37 \pm 0.74 \mathrm{c}$ & $5.56 \pm 11.12 \mathrm{c}$ & $9.22 \pm 4.96 \mathrm{~b}$ & LV 184 & $3.07 \pm 0.47 b$ & $5.10 \pm 6.98 b$ & $0.97 \pm 1.11 \mathrm{a}$ \\
\hline LV 146 & $4.41 \pm 0.31 \mathrm{~d}$ & $7.13 \pm 4.65 \mathrm{~d}$ & $6.98 \pm 2.14 b$ & LV 185 & $3.77 \pm 0.53 \mathrm{c}$ & $6.15 \pm 7.94 \mathrm{c}$ & $0.53 \pm 0.18 \mathrm{a}$ \\
\hline LV 147 & $3.50 \pm 0.20 \mathrm{c}$ & $5.75 \pm 3.00 \mathrm{c}$ & $5.03 \pm 1.43 \mathrm{~b}$ & LV 186 & $4.50 \pm 0.27 \mathrm{~d}$ & $7.25 \pm 4.04 \mathrm{~d}$ & $1.60 \pm 1.19 \mathrm{a}$ \\
\hline LV 148 & $3.45 \pm 0.73 \mathrm{c}$ & $5.68 \pm 10.97 c$ & $0.93 \pm 1.06 \mathrm{a}$ & LV 187 & $1.76 \pm 0.37 \mathrm{a}$ & $3.15 \pm 5.51 \mathrm{a}$ & $4.05 \pm 2.37 \mathrm{~b}$ \\
\hline LV 149 & $3.48 \pm 0.39 \mathrm{c}$ & $5.35 \pm 1.73 b$ & $12.18 \pm 6.18 \mathrm{c}$ & LV 188 & $4.08 \pm 0.37 \mathrm{~d}$ & $6.63 \pm 5.56 \mathrm{~d}$ & $4.65 \pm 2.36 \mathrm{~b}$ \\
\hline LV 152 & $2.83 \pm 0.31 b$ & $4.75 \pm 4.65 b$ & $10.15 \pm 2.90 \mathrm{~b}$ & LV 189 & $2.77 \pm 0.42 b$ & $4.65 \pm 6.35 b$ & $6.83 \pm 3.31 b$ \\
\hline LV 153 & $3.03 \pm 0.25 b$ & $5.08 \pm 3.77 \mathrm{~b}$ & $9.00 \pm 5.81 \mathrm{~b}$ & LV 190 & $2.83 \pm 0.45 b$ & $4.75 \pm 11.21 b$ & $1.23 \pm 0.73 \mathrm{a}$ \\
\hline LV 154 & $3.18 \pm 0.48 b$ & $5.28 \pm 7.18 b$ & $0.65 \pm 0.28 \mathrm{a}$ & LV 191 & $4.32 \pm 0.39 \mathrm{~d}$ & $6.98 \pm 5.91 \mathrm{~d}$ & $2.13 \pm 1.37 \mathrm{a}$ \\
\hline LV 155 & $2.41 \pm 0.27 \mathrm{a}$ & $4.13 \pm 4.03 \mathrm{a}$ & $0.13 \pm 0.08 \mathrm{a}$ & LV 192 & $3.35 \pm 0.75 \mathrm{c}$ & $5.53 \pm 11.24 \mathrm{c}$ & $10.92 \pm 7.30 \mathrm{~b}$ \\
\hline LV 156 & $2.95 \pm 0.55 b$ & $4.93 \pm 8.22 b$ & $9.98 \pm 3.06 b$ & LV 193 & $2.59 \pm 0.85 b$ & $4.38 \pm 12.71 b$ & $0.47 \pm 0.25 \mathrm{a}$ \\
\hline LV 157 & $3.06 \pm 0.32 b$ & $5.10 \pm 4.76 b$ & $11.12 \pm 6.44 b$ & LV 194 & $3.03 \pm 0.39 b$ & $5.05 \pm 5.80 \mathrm{~b}$ & $3.27 \pm 2.97 \mathrm{a}$ \\
\hline LV 158 & $3.53 \pm 0.40 \mathrm{c}$ & $5.80 \pm 5.94 \mathrm{c}$ & $2.08 \pm 1.40 \mathrm{a}$ & LV 195 & $3.53 \pm 0.63 c$ & $5.80 \pm 9.49 \mathrm{c}$ & $1.25 \pm 0.62 \mathrm{a}$ \\
\hline LV 159 & $3.73 \pm 0.16 \mathrm{c}$ & $6.10 \pm 2.45 c$ & $3.02 \pm 3.67 \mathrm{a}$ & LV 196 & $2.95 \pm 0.25 b$ & $4.93 \pm 3.77 b$ & $3.92 \pm 3.99 \mathrm{a}$ \\
\hline LV 160 & $2.90 \pm 0.34 b$ & $4.85 \pm 5.07 b$ & $0.68 \pm 0.42 \mathrm{a}$ & LV 197 & $2.60 \pm 0.36 b$ & $4.40 \pm 5.35 b$ & $2.70 \pm 1.69 \mathrm{a}$ \\
\hline LV 161 & $3.10 \pm 0.42 b$ & $5.15 \pm 6.24 b$ & $3.83 \pm 0.80 b$ & LV 198 & $3.77 \pm 0.25 \mathrm{c}$ & $6.15 \pm 3.70 \mathrm{c}$ & $9.53 \pm 5.00 \mathrm{~b}$ \\
\hline LV 162 & $3.23 \pm 0.24 b$ & $5.35 \pm 3.70 b$ & $1.47 \pm 0.85 \mathrm{a}$ & LV 199 & $4.15 \pm 0.26 \mathrm{~d}$ & $6.75 \pm 4.12 \mathrm{~d}$ & $7.08 \pm 2.92 \mathrm{~b}$ \\
\hline LV 163 & $2.03 \pm 0.28 \mathrm{a}$ & $3.55 \pm 4.20 \mathrm{a}$ & $4.43 \pm 2.54 \mathrm{~b}$ & LV 200 & $3.12 \pm 0.43 b$ & $5.18 \pm 6.40 b$ & $15.37 \pm 3.82 \mathrm{c}$ \\
\hline LV 164 & $3.37 \pm 0.52 \mathrm{c}$ & $5.55 \pm 7.85 \mathrm{c}$ & $1.57 \pm 0.94 \mathrm{a}$ & LV 201 & $3.37 \pm 0.40 \mathrm{c}$ & $5.55 \pm 5.92 \mathrm{c}$ & $6.80 \pm 2.95 b$ \\
\hline LV 165 & $3.52 \pm 0.23 \mathrm{c}$ & $5.78 \pm 3.50 \mathrm{c}$ & $9.70 \pm 1.47 \mathrm{~b}$ & LV 202 & $3.12 \pm 0.31 b$ & $5.18 \pm 4.72 \mathrm{c}$ & $3.28 \pm 2.61 \mathrm{a}$ \\
\hline LV 166 & $3.37 \pm 0.27 \mathrm{c}$ & $5.55 \pm 4.04 \mathrm{c}$ & $2.45 \pm 1.42 \mathrm{a}$ & LV 203 & $3.60 \pm 0.52 \mathrm{c}$ & $5.90 \pm 7.79 \mathrm{c}$ & $1.90 \pm 1.17 \mathrm{a}$ \\
\hline LV 167 & $2.68 \pm 0.36 b$ & $4.53 \pm 5.38 \mathrm{~b}$ & $2.08 \pm 2.18 \mathrm{a}$ & LV 204 & $3.82 \pm 0.69 \mathrm{c}$ & $6.23 \pm 10.34 \mathrm{c}$ & $10.18 \pm 1.55 b$ \\
\hline
\end{tabular}

${ }^{\mathrm{z}}$ Mean values in columns followed by the same letter are not significantly different, according to the Scott-Knott test $(P=0.05)$. 
compatible isolates indicates that genetic information to complete the sexual cycle is not available in these individuals, although the initial phase of reproduction has been demonstrated. Another hypothesis that could explain these results is the absence of any environmental stimuli, such as nutrients, temperature, or lighting, to induce the pathogen's complete sexual cycle.
The fusion of vegetative hyphae to form heterokaryons is a prerequisite for the occurrence of the parasexual cycle $(8,11)$. Our results indicate that mycelium compatibility was not observed between tested isolates, indicating that the isolates belong to different vegetative compatibility groups (VCGs). The occurrence of a large number of VCGs in C. lindemuthianum has been de-

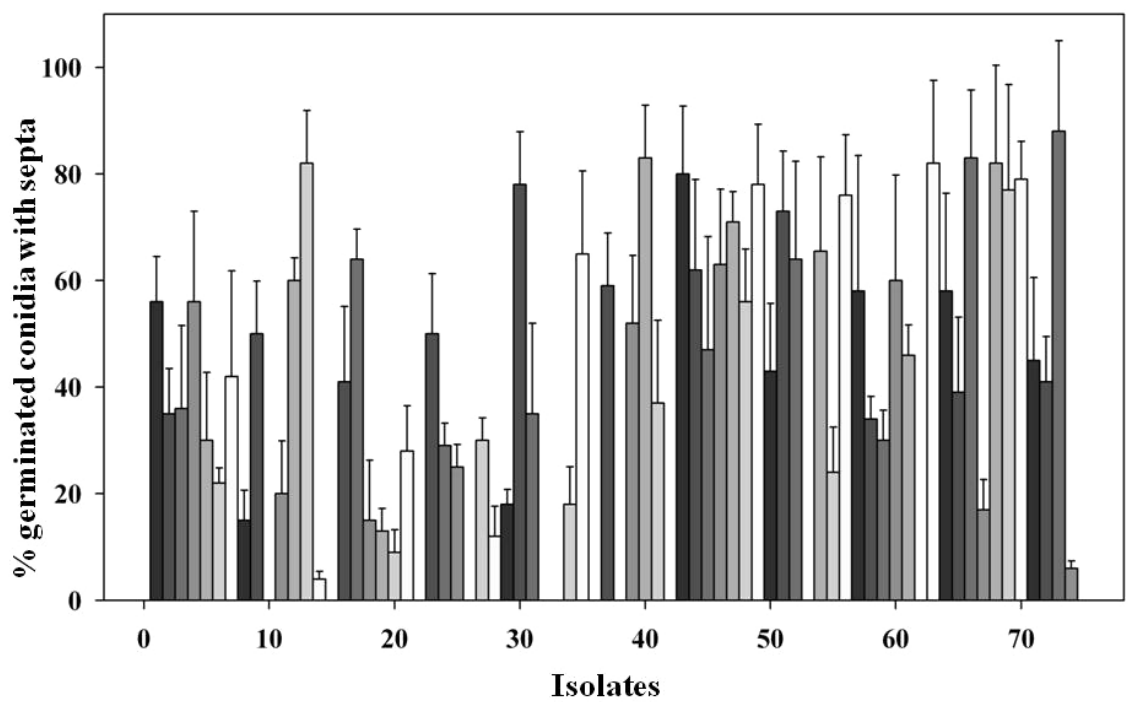

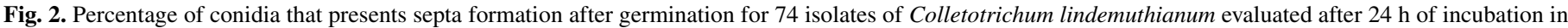
water and stained with Calcofluor White $(0.12 \mathrm{M})$. Bars represent standard deviation from mean values of two replicates.

TABLE 3. Mean values and standard errors for conidial germination, conidial anastomosis tube (CATs) fusion, and conidia measurements from 74 Colletotrichum lindemuthianum isolates investigated

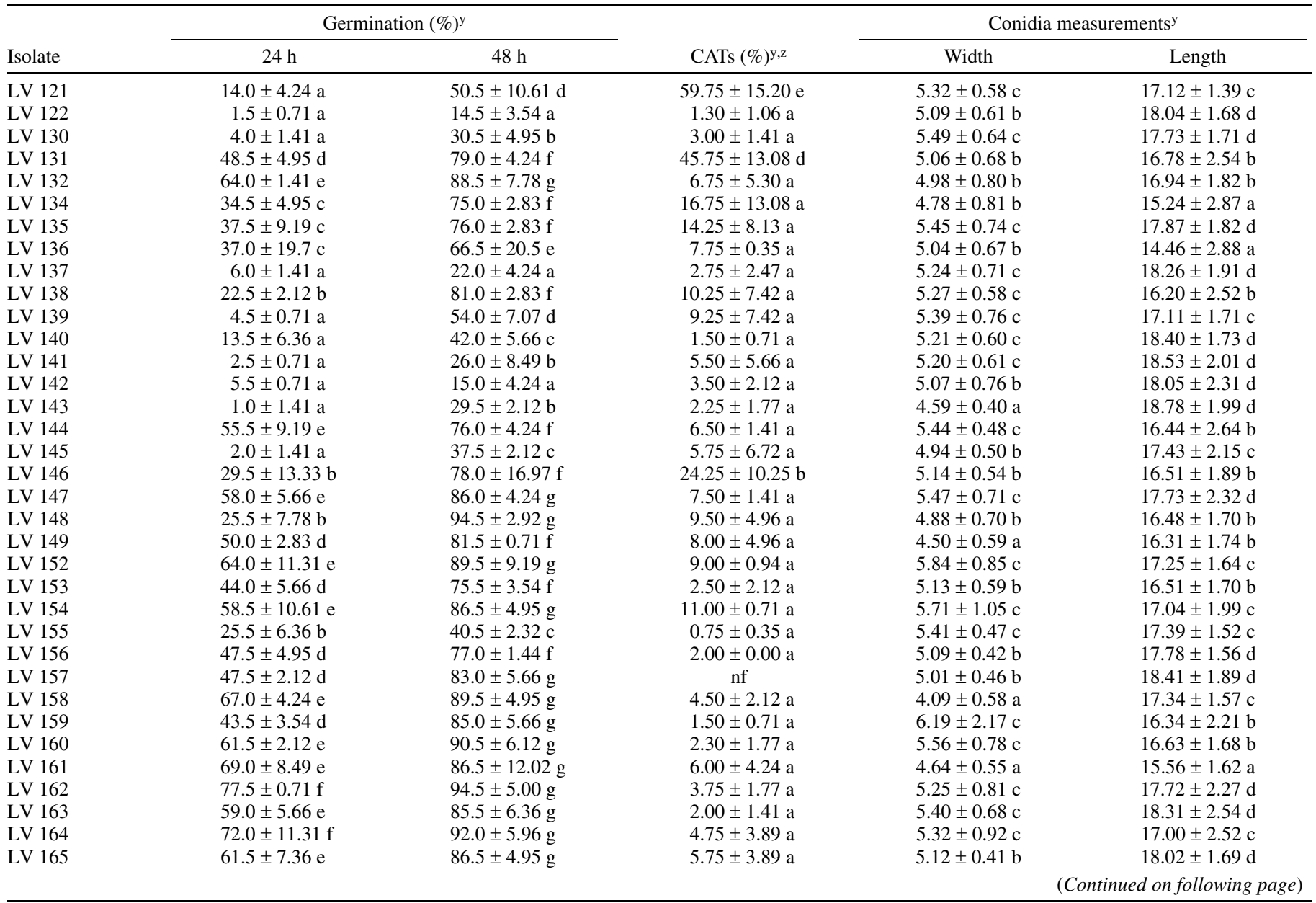

y Mean values in columns followed by the same letter are not significantly different, according to the Scott-Knott test $(P=0.05)$.

$\mathrm{z}$ Abbreviation: $\mathrm{nf}=$ CATs fusion were not observed for this isolate. 


\begin{tabular}{|c|c|c|c|c|c|}
\hline \multirow[b]{2}{*}{ Isolate } & \multicolumn{2}{|c|}{ Germination $(\%)^{\mathrm{y}}$} & \multirow[b]{2}{*}{ CATs $(\%)^{\mathrm{y}, \mathrm{z}}$} & \multicolumn{2}{|c|}{ Conidia measurements ${ }^{\mathrm{y}}$} \\
\hline & $24 \mathrm{~h}$ & $48 \mathrm{~h}$ & & Width & Length \\
\hline LV 166 & $11.0 \pm 1.41 \mathrm{a}$ & $47.0 \pm 19.80 \mathrm{~d}$ & $8.50 \pm 7.78 \mathrm{a}$ & $5.48 \pm 0.59 \mathrm{c}$ & $17.12 \pm 2.05 \mathrm{c}$ \\
\hline LV 167 & $4.0 \pm 0.00 \mathrm{a}$ & $82.5 \pm 2.03 \mathrm{~g}$ & $1.50 \pm 0.71 \mathrm{a}$ & $5.38 \pm 0.61 \mathrm{c}$ & $16.14 \pm 1.99 \mathrm{~b}$ \\
\hline LV 168 & $30.0 \pm 11.31 \mathrm{~b}$ & $46.5 \pm 9.19 \mathrm{~d}$ & $2.75 \pm 2.47 \mathrm{a}$ & $5.27 \pm 0.72 \mathrm{c}$ & $17.23 \pm 2.18 \mathrm{c}$ \\
\hline LV 169 & $8.0 \pm 7.07 \mathrm{a}$ & $66.5 \pm 6.36 \mathrm{e}$ & $8.50 \pm 3.53 \mathrm{a}$ & $5.12 \pm 0.69 \mathrm{~b}$ & $17.64 \pm 2.17 \mathrm{c}$ \\
\hline LV 170 & $66.5 \pm 14.85 \mathrm{e}$ & $88.0 \pm 9.90 \mathrm{~g}$ & $6.00 \pm 1.41 \mathrm{a}$ & $5.49 \pm 0.51 \mathrm{c}$ & $17.08 \pm 1.92 \mathrm{c}$ \\
\hline LV 171 & $25.5 \pm 3.36 \mathrm{~b}$ & $53.0 \pm 8.49 \mathrm{~d}$ & $1.50 \pm 1.89 \mathrm{a}$ & $5.30 \pm 0.57 \mathrm{c}$ & $16.80 \pm 2.59 b$ \\
\hline LV 172 & $4.0 \pm 1.41 \mathrm{a}$ & $94.5 \pm 0.71 \mathrm{~g}$ & $2.00 \pm 0.71 \mathrm{a}$ & $4.99 \pm 0.87 b$ & $15.84 \pm 1.95 \mathrm{a}$ \\
\hline LV 173 & $47.5 \pm 11.92 \mathrm{~d}$ & $85.5 \pm 12.02 \mathrm{~g}$ & $6.50 \pm 5.66 \mathrm{a}$ & $5.20 \pm 0.64 \mathrm{c}$ & $16.85 \pm 2.03 b$ \\
\hline LV 174 & $41.0 \pm 1.41 \mathrm{c}$ & $94.0 \pm 1.36 \mathrm{~g}$ & $22.00 \pm 13.43 \mathrm{~b}$ & $5.23 \pm 0.70 \mathrm{c}$ & $17.63 \pm 2.25 \mathrm{c}$ \\
\hline LV 175 & $28.5 \pm 3.54 \mathrm{~b}$ & $53.5 \pm 7.78 \mathrm{~d}$ & $2.00 \pm 1.41 \mathrm{a}$ & $5.31 \pm 0.91 \mathrm{c}$ & $17.09 \pm 2.24 \mathrm{c}$ \\
\hline LV 176 & $25.5 \pm 2.12 b$ & $80.0 \pm 4.24 \mathrm{f}$ & $1.50 \pm 1.82 \mathrm{a}$ & $5.25 \pm 0.57 \mathrm{c}$ & $16.56 \pm 1.72 b$ \\
\hline LV 177 & $44.0 \pm 8.49 \mathrm{~d}$ & $90.5 \pm 4.97 \mathrm{~g}$ & $8.25 \pm 5.30 \mathrm{a}$ & $5.21 \pm 0.68 \mathrm{c}$ & $17.44 \pm 2.18 \mathrm{c}$ \\
\hline LV 178 & $40.0 \pm 4.24 \mathrm{c}$ & $84.0 \pm 5.68 \mathrm{~g}$ & $\mathrm{nf}$ & $5.24 \pm 0.59 \mathrm{c}$ & $16.79 \pm 2.06 \mathrm{~b}$ \\
\hline LV 179 & $61.0 \pm 18.38 \mathrm{e}$ & $83.0 \pm 11.31 \mathrm{~g}$ & $3.00 \pm 1.82 \mathrm{a}$ & $5.13 \pm 0.84 b$ & $17.99 \pm 2.34 \mathrm{~d}$ \\
\hline LV 180 & $45.0 \pm 4.24 \mathrm{~d}$ & $77.5 \pm 4.95 \mathrm{f}$ & $1.50 \pm 0.71 \mathrm{a}$ & $5.11 \pm 0.74 b$ & $17.40 \pm 1.38 \mathrm{c}$ \\
\hline LV 181 & $37.0 \pm 1.41 \mathrm{c}$ & $85.0 \pm 2.83 \mathrm{~g}$ & $1.75 \pm 1.14 \mathrm{a}$ & $4.94 \pm 0.78 b$ & $16.22 \pm 2.05 b$ \\
\hline LV 182 & $35.0 \pm 8.49 \mathrm{c}$ & $58.5 \pm 10.61 \mathrm{~d}$ & $1.50 \pm 1.41 \mathrm{a}$ & $4.96 \pm 0.63 b$ & $17.77 \pm 1.13 \mathrm{~d}$ \\
\hline LV 183 & $43.0 \pm 9.90 \mathrm{~d}$ & $80.0 \pm 4.24 \mathrm{f}$ & $2.25 \pm 1.77 \mathrm{a}$ & $5.45 \pm 0.81 \mathrm{c}$ & $16.74 \pm 2.14 b$ \\
\hline LV 184 & $42.5 \pm 17.48 \mathrm{~d}$ & $77.0 \pm 16.87 \mathrm{f}$ & $\mathrm{nf}$ & $5.04 \pm 0.51 b$ & $16.28 \pm 2.42 b$ \\
\hline LV 185 & $53.0 \pm 8.49 \mathrm{~d}$ & $89.0 \pm 6.18 \mathrm{~g}$ & $12.80 \pm 8.13 \mathrm{a}$ & $5.39 \pm 0.90 \mathrm{c}$ & $15.19 \pm 2.15 \mathrm{a}$ \\
\hline LV 186 & $6.0 \pm 4.24 \mathrm{a}$ & $59.0 \pm 5.36 \mathrm{~d}$ & $3.00 \pm 2.83 \mathrm{a}$ & $5.31 \pm 1.05 \mathrm{c}$ & $17.11 \pm 1.83 \mathrm{c}$ \\
\hline LV 187 & $4.0 \pm 2.83 \mathrm{a}$ & $26.0 \pm 9.90 \mathrm{a}$ & $2.25 \pm 1.06 \mathrm{a}$ & $4.91 \pm 0.39 b$ & $16.78 \pm 1.93 b$ \\
\hline LV 188 & $7.0 \pm 2.83 \mathrm{a}$ & $42.0 \pm 5.65 \mathrm{c}$ & $1.75 \pm 1.06 \mathrm{a}$ & $5.08 \pm 0.50 b$ & $15.64 \pm 2.45 \mathrm{a}$ \\
\hline LV 189 & $22.5 \pm 10.6 b$ & $47.5 \pm 19.09 \mathrm{~d}$ & $4.50 \pm 3.53 \mathrm{a}$ & $4.95 \pm 0.34 b$ & $16.68 \pm 1.14 b$ \\
\hline LV 190 & $88.5 \pm 12.02 \mathrm{~g}$ & $94.5 \pm 4.76 \mathrm{~g}$ & $27.20 \pm 5.30 \mathrm{~b}$ & $5.06 \pm 0.62 b$ & $18.25 \pm 1.84 \mathrm{~d}$ \\
\hline LV 191 & $16.0 \pm 8.49 \mathrm{a}$ & $42.0 \pm 2.97 \mathrm{c}$ & $4.00 \pm 3.53 \mathrm{a}$ & $5.10 \pm 0.55 b$ & $16.17 \pm 1.75 b$ \\
\hline LV 192 & $8.0 \pm 4.24 \mathrm{a}$ & $30.5 \pm 2.27 b$ & $11.75 \pm 3.18 \mathrm{a}$ & $5.19 \pm 0.65 \mathrm{c}$ & $17.01 \pm 2.51 \mathrm{c}$ \\
\hline LV 193 & $63.0 \pm 16.97 \mathrm{e}$ & $90.0 \pm 9.85 \mathrm{~g}$ & $1.55 \pm 6.36 \mathrm{a}$ & $5.05 \pm 0.57 b$ & $15.59 \pm 1.78 \mathrm{a}$ \\
\hline LV 194 & $25.5 \pm 3.54 b$ & $54.5 \pm 9.19 \mathrm{~d}$ & $5.75 \pm 2.47 \mathrm{a}$ & $5.05 \pm 0.96 b$ & $17.08 \pm 2.79 \mathrm{c}$ \\
\hline LV 195 & $26.5 \pm 3.54 \mathrm{~b}$ & $50.5 \pm 2.49 \mathrm{~d}$ & $51.50 \pm 0.94 \mathrm{~d}$ & $4.44 \pm 0.52 \mathrm{a}$ & $15.93 \pm 2.11 \mathrm{a}$ \\
\hline LV 196 & $72.5 \pm 3.54 \mathrm{f}$ & $94.0 \pm 2.83 \mathrm{~g}$ & $3.50 \pm 0.71 \mathrm{a}$ & $5.17 \pm 0.55 b$ & $16.66 \pm 2.05 b$ \\
\hline LV 197 & $8.5 \pm 6.36 \mathrm{a}$ & $38.5 \pm 12.02 \mathrm{c}$ & $1.75 \pm 1.06 \mathrm{a}$ & $4.76 \pm 0.53 b$ & $17.84 \pm 1.59 \mathrm{~d}$ \\
\hline LV 198 & $71.5 \pm 4.95 \mathrm{e}$ & $91.5 \pm 6.36 \mathrm{~g}$ & $36.25 \pm 13.08 c$ & $5.16 \pm 0.52 b$ & $15.56 \pm 2.07 \mathrm{a}$ \\
\hline LV 199 & $1.5 \pm 2.12 \mathrm{a}$ & $26.0 \pm 4.24 \mathrm{~b}$ & $2.00 \pm 0.71 \mathrm{a}$ & $5.76 \pm 0.94 \mathrm{c}$ & $18.08 \pm 1.35 \mathrm{~d}$ \\
\hline LV 200 & $4.0 \pm 1.41 \mathrm{a}$ & $33.0 \pm 2.98 b$ & $4.00 \pm 4.24 \mathrm{a}$ & $4.86 \pm 0.59 b$ & $16.81 \pm 2.40 \mathrm{~b}$ \\
\hline LV 201 & $4.0 \pm 1.41 \mathrm{a}$ & $28.5 \pm 3.54 b$ & $\mathrm{nf}$ & $5.01 \pm 0.58 b$ & $16.87 \pm 2.28 b$ \\
\hline LV 202 & $27.5 \pm 3.54 \mathrm{~b}$ & $65.5 \pm 6.78 \mathrm{e}$ & $3.25 \pm 1.77 \mathrm{a}$ & $5.06 \pm 0.76 b$ & $16.86 \pm 2.10 b$ \\
\hline LV 203 & $10.5 \pm 3.56 \mathrm{a}$ & $35.5 \pm 10.6 b$ & $3.58 \pm 0.94 \mathrm{a}$ & $5.39 \pm 0.61 \mathrm{c}$ & $17.43 \pm 1.66 \mathrm{c}$ \\
\hline LV 204 & $37.0 \pm 5.66 \mathrm{c}$ & $73.0 \pm 8.49 \mathrm{f}$ & $24.00 \pm 5.66 b$ & $5.37 \pm 0.52 \mathrm{c}$ & $16.76 \pm 1.71 b$ \\
\hline
\end{tabular}

scribed. Barcelos et al. (3) observed the formation of 45 VCGs: 44 isolates were incompatible and only 1 combination successfully formed heterokaryons, demonstrating the wide species variability for this trait. In addition, vegetative incompatibility is common in natural populations of filamentous fungi and could limit the occurrence of the parasexual cycle in nature (8).

An alternative method of asexual recombination between incompatible isolates, CAT fusion, has been suggested by Ishikawa (13). In this study, we observed that CAT fusion is common for most of the isolates $(94.6 \%)$ analyzed. Whereas CATs have an important role in the pathogen's population dynamics, the high frequency may significantly influence the variability of pathogen populations. Previous work has shown that CAT fusion occurs only in water and that it is dependent on the culture age (e.g., it occurs more often in older colonies) and strain used (e.g., the highest percentage of CAT fusion was $25.8 \%$ for race 65 isolate LV 115) (16). One advantage for using large populations for characterization studies is the possibility of finding extreme phenotypes. In this study, five isolates had CAT percentages that were higher than previously reported (>25\%) (Table 3). LV 121 showed a higher percentage of CAT fusion $(\approx 60 \%)$, close to what is found for Neurospora crassa (30). These isolates could be used in future studies to elucidate the role of CATs in genetic variation, pathogenicity, and population dynamics. Furthermore, all strains that present CAT extreme values belongs to race 65 , except isolate LV121 (race 64); and, interestingly, all the strains showed high susceptibility to commercial fungicide. A high percentage of CATs can be a possible strategy of these isolates to change genetic information to seek resistance to one of the fungicides most used in the field for anthracnose.

Our main findings were as follows: (i) genetic and morphological variations occurred between race 65 isolates; (ii) $C$. lindemuthianum isolates demonstrated wide variations in morphological and physiological analyses and could not be grouped by origin or race; (iii) resistance to the fungicide thiophanate-methyl is strain dependent for $C$. lindemuthianum; (iv) CAT fusion occurred at higher frequencies in these populations, specially isolate LV 121 (60\%); and (v) C. lindemuthianum conidia can form septa after germination, which is strain dependent. The information gathered in this study can be applied in future studies: basic knowledge (e.g., cell biology and genetics of pathogenic fungi), applied areas in phytopathology (e.g., management and control of disease), and plant breeding for resistance to C. lindemuthianum races are of great importance in the region.

\section{ACKNOWLEDGMENTS}

The authors are grateful to Coordenadoria de Aperfeiçoamento de Pessoal de Nível Superior (CAPES), Conselho Nacional de Desenvolvimento Científico e Tecnológico $(\mathrm{CNPq})$ and Fundação de Apoio à Pesquisa do Estado de Minas Gerais (FAPEMIG), for a scholarship and for the financial support.

\section{LITERATURE CITED}

1. Abreu, A. F. B. 2005. Cultivo do feijão da primeira e segunda safras na região sul de Minas Gerais. Embrapa Arroz e Feijão, Sistemas de 
Produção n. 6.

2. Bailey, J. A., and Jeger, M. J. 1992. Colletotrichum: Biology, Pathology and Control. CAB International, Wallingford, UK.

3. Barcelos, Q. L., Souza, E. A., and Silva, K. J. D. 2011. Vegetative compatibility and genetic analysis of Colletotrichum lindemuthianum isolates from Brazil. Gen. Mol. Res. 10:230-242.

4. Bergamin, A., Kimati, H., and Amorim, L. 1995. Manual de Fitopatologia, Vol 1. Agronomica Ceres, São Paulo.

5. Box, G. E., and Cox, D. R. 1964. An analysis of transformed data. J. R. Stat. Soc. 39:211-252.

6. Camargo Junior, A. O., Souza, E. A., Mendes-Costa, M. C., Santos, J. B., and Soares, M. A. 2007. Identification of Glomerella cingulata f. sp. phaseoli recombinants by RAPD markers. Genet. Mol. Res. 6:607-615.

7. Castro-Prado, M. A. A., Querol, C. B., Santana, J. R., Miyamoto, C. T., Franco, C. C. S., Mangolin, C. A., and Machado, M. F. P. S. 2007. Vegetative compatibility and parasexual segregation in Colletotrichum lindemuthianum, a fungal pathogen of the common bean. Gen. Mol. Res. 6:634-642.

8. Clutterbuck, A. J. 1996. Parasexual recombination in fungi. J. Genet. 75:281-286.

9. Dias, M. D. 2002. Caracterização morfológica, bioquímica e patogênica de isolados de Colletotrichum spp. em Coffea arabica L. Dissertação de Mestrado, Universidade Federal de Lavras, Brazil.

10. García-Serrano, M., Laguna, E. A., Rodriguez-Guerra, R., and Simpson, J. 2008. Analysis of the MAT1-2-1 gene of Colletotrichum lindemuthianum. Mycoscience 49:312-317.

11. Glass, N. L., Ramussen, C., Roca, M. G., and Read, N. D. 2004. Hyphal homing, fusion and mycelial interconnectedness. Trend. Microbiol. 12:135-141.

12. Habgood, R. M. 1970. Designation of physiological races of plant pathogens. Nature 227:1268-1269.

13. Ishikawa, F. H., Souza, E. A., Shoji, J., Connolly, L., Freitag, M., Read, N. D., and Roca, M. G. Heterokaryon incompatibility is suppressed following conidial anastomosis tube fusion in a fungal plant pathogen. Plos (In Press.)

14. Ishikawa, F. H., Barcelos, Q. L., Alves, E., Camargo Junior, O. A., and Souza, E. A. 2010. Symptoms and pre-penetration events associated with the infection of common bean by the anamorph and teleomorph of Glomerella cingulata f. sp. phaseoli. J. Phytopathol. 158:270-277.

15. Ishikawa, F. H., Souza, E. A., and Davide, L. M. C. 2008. Genetic variability within isolates of Colletotrichum lindemuthianum belonging to race 65 from the state of Minas Gerais, Brazil. Bratislava 63:156-161.

16. Ishikawa, F. H., Souza, E. A., Read, N. D., and Roca, M. G. 2010. Livecell imaging of conidial fusion in the bean pathogen, Colletotrichum lindemuthianum. Fungal Biol. 114:2-9.

17. Kimati, H., Amorim, L., Bergamin Filho, A., Camargo, L. E. A., and Rezende, J. A. M. 1997. Pages 383-385 in: Manual de fitopatologia: doenças das plantas cultivadas, vol. 2, 2nd ed. Agronômica Ceres, São Paulo, Brazil.

18. O'Connell, R. J., Nash, C., and Bailey, J. A. 1992. Lectin citochesmitry: a new approach to understanding cell differentiation, pathogenesis and taxonomy in Colletotrichum. Pages 67-87 in: Colletotrichum: Biology, Pathology and Control. J. A. Bayley and M. J. Jeger, eds. CAB International, Wallingford, UK.

19. Oliveira, J. A. 1991. Efeito do tratamento fungicida em sementes no controle de tombamento de plântulas de pepino (Cucumis sativus L.) e pimentão (Capsicum annum L.). Dissertação de Mestrado, Universidade Federal de Lavras, Brazil.

20. Pastor-Corrales, M. A. 1991. Estandarización de variedades diferenciales y de designación de razas de Colletotrichum lindemuthianum. (Abstr.) Phytopathology 81:694.

21. Pereira, A. L., Silva, G. S., and Ribeiro, V. Q. 2006. Caracterização fisiológica, cultural e patogênica de diferentes isolados de Lasiodiplodia theobromae. Fitopatol. Brasil. 31:572-578.

22. Pereira, R., Ishikawa, F. H., Pinto, J. M. A., and Souza, E. A. 2010. Occurrence of anthracnose in common bean cultivars collected in the state of Minas Gerais, Brazil. Annu. Rep. Bean Improv. Coop. 53:224-225.

23. Pinto, J. M. A., Souza, E. A., and Oliveira, D.F. 2010. Use of plant extracts in the control of common bean anthracnose. Crop Prot. 29:838-842.

24. Raeder, U., and Broda, P. 1985. Rapid preparation of DNA from filamentous fungi. Appl. Microbiol. 1:17-20.

25. Rava, A. C., Molina, J., Kauffman, M., and Briones, I. 1993. Determinacion de razas fisiológicas de Colletotrichum lindemuthianum en Nicarágua. Fitopatol. Bras. 18:388-391.

26. Rava, A. C., Purchio, A. F., and Sartorato, A. 1994. A caracterização de patótipos de Colletotrichum lindemuthianum que ocorrem em algumas regiões produtoras de feijoeiro comum. Fitopatol. Bras. 19:167-172.

27. Rava, A. C., and Sartorato, A. 1994. Antracnose. Pages 17-40 in: Principais doenças do feijoeiro comum e seu controle. A. C. Rava and A. Sartorato, eds. Embrapa, Brasília.

28. Roca, M. G., Davide, L. C., Davide, L. M., Mendes-Costa, M. C., Schwan, R., and Wheals, A. E. 2004. Conidial anastomosis fusion between Colletotrichum spp. Mycol. Res.108:1320-1326.

29. Roca, M. G., Davide, L. C., and Mendes-Costa, M. C. 2003. Cytogenetics of Colletotrichum lindemuthianum (Glomerella cingulata f. sp. phaseoli). Fitopatol. Bras. 28:367-373.

30. Roca, M. G., Kuo, H. C., Lichius, A., Freitag, M., and Read, N. D. 2010. Nuclear dynamics, mitosis, and the cytoskeleton during the early stages of colony initiation in Neurospora crassa. Eukarot. Cell 9:1171-1183.

31. Shattock, R. C. 1988. Studies on the inheritance of resistance to metalaxyl in Phytophthora infestans. Plant Pathol. 37:4-11.

32. Shear, C. L., and Wood, A. K. 1913. Studies of fungus parasites belonging to the genus Glomerella. U.S. Dep. Agric. Bureau Plant Ind. Bull. 252. Washington, DC.

33. Silva, K. J. D., Souza, E. A., and Ishikawa, F. H. 2007. Characterization of Colletotrichum lindemuthianum isolates from the state of Minas Gerais, Brazil. J. Phytopathol. 155:241-247.

34. Souza, B. O., Souza, E. A., and Mendes-Costa, M. C. 2007. Determinação da variabilidade em isolados de Colletotrichum lindemuthianum por meio de marcadores morfológicos e culturais. Ciênc. Agrotec. 31:10001006.

35. Souza, E. A., Camargo Junior, O. A., and Pinto, J. M. A. 2010. Sexual recombination in Colletotrichum lindemuthianum occurs on a fine scale. Gen. Mol. Res. 9:1759-1769.

36. Sutton, B. C. 1992. The genus Glomerella and its Anamorph Colletotrichum. Pages 1-26 in: Colletotrichum: Biology, Pathology and Control. J. A. Bayley and M. J. Jeger, eds. CAB International, Wallingford, UK.

37. Talamini, V., Souza, E. A., Pozza E. A., Carrijo, F. R. F., Ishikawa, F. H., Silva, K. J. D., and Oliveira, F. A. 2004. Identificação de raças patogênicas de Colletotrichum lindemuthianum a partir de isolados provenientes de regiões produtoras de feijoeiro comum. Summa Phytopathol. 30:371-375.

38. Talamini, V., and Stadnik, M. J. 2004. Extratos vegetais e algas no controle de doenças de plantas. Page 45-62 in: Manejo ecológico de doenças de plantas. M. J. Stadnik and V. Talamini, eds. UFSC, Florianópolis.

39. Vaillancourt, L., Wang, J., and Hanau, R. 2000. Genetic regulation of sexual compatibility in Glomerella graminicola. Pages 29-44 in: Colletotrichum: Host Specificity, Pathology, and Host-Pathogen Interaction. D. Prusky, S. Reeman, and M. B. Dickman, eds. American Phytopathological Society, St. Paul, MN.

40. Wood, R. K. S., and Jellis, G. J. 1984. Plant Diseases: Infection, Damage and Loss. Blackwell Scientific Publications, Oxford.

41. Wordell Filho, J. A. 2004. Manejo ecológico de doenças de plantas em Santa Catarina. Pages 31-46 in: Manejo ecológico de doenças de plantas. M. J. Stadnik and V. Talamini, eds. UFSC, Florianópolis. 